\title{
Views on Effective Leadership from Insiders and Outsiders
}

\author{
Terri R. Lituchy, CETYS Universidad, Mexicali, Mexico \\ Elham Kamal Metwally, American University in Cairo, Egypt \\ Courtney Aleise Henderson, Berkeley College, New York, USA
}

\section{Introduction}

What African managers consider effective leadership may not be the same as what is seen as effective by expatriates. As part of the LEAD project, insights from local African leaders (insiders) and expatriate leaders (outsiders) were researched. We found that there were very few differences and mostly commonalities between insider (locals) and outsider (expatriates) leaders interviewed. Some commonalities included: using an authoritarian leadership style, sharing a clear vision, and understanding and respecting the culture, norms and taboos of the people, and the business environment to gain acceptance. In this article, insights to culturally-appropriate effective leadership are provided. Implications include incorporating best leadership practices from other parts of the world into African organizations.

As outlined in the first paper in this issue and elsewhere (Aseidu-Appiah, Agyapong, \& Lituchy, 2017; Lituchy \& Punnett, 2014; Lituchy, Galperin \& Punnett, 2016; Mengitsu \& Lituchy, 2017; Metwally \& Punnett, 2017) the LEAD research project uses an emic-etic-emic research cycle. This paper presents initial results of the second round of emic data collection, interviews with local leaders and expatriate leaders, "insiders" and "outsiders," respectively. These interviews sought to understand the two groups thinking on effective leadership and to identify commonalities and contrasts between them.

Thinking in the leadership field has evolved substantially over the past century. Current leadership theories and models of effective leaders focus on transformational, visionary, authentic, and adaptive leadership (Avolio, Walumbwa \& Weber, 2009; Northouse, 2016). Avolio et al. (2009) identified the field as becoming more universal, with more constructive leadership practices being incorporated into the leadership research, the follower becoming essential in the system, and growing interest regarding antecedents of leadership, e-leadership, and shared leadership in organizations. Leadership today is viewed as a complex process that evolves in organizations. This view can account for some of the unexpected similarities. Northouse (2016) identified multiple dimensions of trait, skills, behaviors, situational approaches, path-goal, leader-member exchange, transformational, authentic, servant, adaptive, psychodynamic, and team leadership. This illustrates the complexity of understanding what makes an effective leader. Avolio et al. (2009) note that "new leadership models emphasized symbolic leader behavior; visionary, inspirational messages; emotional feelings; ideological and moral values; individualized attention; and intellectual stimulation." However, charismatic and transformational leadership have been the most frequently researched theories over the past 20 years.

The focus has still remained on this relationship from the viewpoint of Western leaders (Van Vugt, Hogan, \& Kaisar, 2008; Zhang, et al., 2012). The cross-cultural literature suggests that further research is required in many under-researched areas (Lituchy \& Punnett, 2014; Zhang et al., 2012), and Africa has been singled out for attention. This research needs to be independent of prevailing Western organizational models, to generate better understandings of leadership effectiveness in Africa. In addition to understanding local leadership in Africa, the issue arises as to what makes an effective expatriate. When expatriate leaders use the cultural norms and expectations of leadership from their home country and attempt to operate in that framework in a new country the results are often different than anticipated (Cox, Lobel, \& McLeod, 1991). Osland (2008: 10), in a direct comparison of domestic and expatriate work, found that "expatriates reported significantly higher demands for social and perceptual skills, reasoning ability, and adjustment- and achievement-orientation personality requirements in their work." Cultural norms vary among different groups depending on the profession or sector. This explains how an expatriate leader's behaviors in a new country can be misunderstood by their employees, whom are accustomed to different cultural norms (Cox, et al., 1991). 


\section{The Current Project}

The aim of this paper is to compare and contrast insights on effective leadership from two different perspectives: local leaders (insiders) and expatriate leaders (outsiders) working in several African countries (Ethiopia, Ghana, Kenya, Nigeria, South Africa, Tanzania, and Uganda). This approach can contribute to an African-centered, culturally appropriate understanding of effective leadership. Insights from both insider and outsider leaders can also be incorporated into practice.

As part of the larger LEAD study, 17 insiders (local leaders) and 16 outsiders/expatriates were interviewed. Participants included a CEO, managers, financial officers, professors, deans, administrators, broadcast journalists, a public service director, an inspector, an auditor, bankers, government officers, advisors, and self-employed people. The sample was a purposive non-probability sample that targeted people in leadership positions who could provide the desired information. The participants were told that data collected would be used exclusively for research purposes.

Open-ended questions examined the participants' views about leadership in their countries of residence, challenges faced, and suggestions/advice that they could give to existing leaders, future leaders, and expatriates. These questions were asked to insiders in each country: What is your description of the leadership style in the country you live in? How is this similar to or different from what you observe in foreign visiting managers? What leadership style is most effective in your country? What advice regarding leadership style would you give foreigners coming to your country? These questions were posed to outsiders: To what extent do you have other international experience (living and working outside the home country)? What similarities (to home country) in leadership have you observed in the host African country? What differences (from home country) in leadership have you observed in the host African country? What are your perceptions of the leadership style that is most effective in the host African country? Describe some leadership challenges that you have had in the host African country? What advice regarding leadership style do you have for other foreigners going to the host African country?

Participants were contacted by phone or email. Interviews were conducted face-to-face in English. Content analysis was used to organize and synthesize the data and identify the relevant commonalities and differences between the groups.

\section{Table 1: Commonalities and Differences between Insiders and Outsiders*}

\begin{tabular}{|c|c|c|}
\hline \multicolumn{3}{|c|}{ Commonalities } \\
\hline & Insiders \% & Outsiders \% \\
\hline $\begin{array}{c}\text { Spend time understanding } \\
\text { followers' ideas, problems, } \\
\text { complaints }\end{array}$ & 18 & 13 \\
\hline $\begin{array}{c}\text { Be firm, dictate work, com- } \\
\text { mand people, and adopt an } \\
\text { authoritarian leadership style } \\
\text { to get work done }\end{array}$ & 59 & 13 \\
\hline Share a clear vision & 35 & 19 \\
\hline $\begin{array}{c}\text { Allow mistakes to happen for } \\
\text { people to learn }\end{array}$ & 12 & 6 \\
\hline $\begin{array}{c}\text { Do not tolerate } \\
\text { malpractice }\end{array}$ & 12 & 25 \\
\hline $\begin{array}{c}\text { Delegate authority } \\
\text { gradually, respect authority }\end{array}$ & 6 & 6 \\
\hline
\end{tabular}

\begin{tabular}{|c|c|c|c|}
\hline \multicolumn{4}{|c|}{ Differences } \\
\hline Insiders & $\%$ & Outsiders & $\%$ \\
\hline $\begin{array}{l}\text { Expats should avoid condescending } \\
\text { attitudes that suggest that as a } \\
\text { foreign manager they know better } \\
\text { than locals }\end{array}$ & 41 & $\begin{array}{l}\text { Pay more attention to the basic rights of } \\
\text { employees, have good communication skills, } \\
\text { and be less disappointed when dealing with } \\
\text { subordinates }\end{array}$ & 6 \\
\hline \multirow[t]{5}{*}{$\begin{array}{l}\text { The relationship between leaders } \\
\text { and subordinates is influenced by } \\
\text { their personal relationship with the } \\
\text { subordinates, which is in-turn influ- } \\
\text { enced by religious and ethnic ties }\end{array}$} & 6 & $\begin{array}{l}\text { The traditional African style of leadership } \\
\text { remains the most effective...for democracy and } \\
\text { concern for human rights to mature to the next } \\
\text { level in most parts of Africa, there will need to } \\
\text { be some modifications }\end{array}$ & 6 \\
\hline & & Expats should be approachable & 6 \\
\hline & & Expats should brainstorm with locals & 6 \\
\hline & & $\begin{array}{l}\text { Expats should combine good practices from } \\
\text { other parts of the world }\end{array}$ & 6 \\
\hline & & Expats should work with like-minded people & 6 \\
\hline
\end{tabular}

* 17 insiders (locals) and 16 outsiders (expatriates) 


\section{Interview Results}

There were very few differences between the insiders (locals) and outsiders (expatriates). One difference was that insiders (41\%) thought that outsiders should avoid condescending attitudes that suggest that as a foreign manager they know better than locals. This was not mentioned by outsiders (see Table 1).

Some commonalities include: Be result-oriented, goal-driven, and well-trained and skilled ( $76 \%$ insiders; $44 \%$ outsiders); Be serious; fair; honest; respect time; and show integrity in terms of managerial and public leadership (47\% insiders; $50 \%$ outsiders); A mixed leadership style is appropriate (59\% insiders; $19 \%$ outsiders); Be firm, dictate work, command people, and adopt an authoritarian leadership style to get work done (59\% insiders; $13 \%$ outsiders); Focus on capacity-building, developing subordinated, and accountability (35\% insiders; $31 \%$ outsiders); and, Share a clear vision (35\% insiders; $19 \%$ outsiders).

In addition both insiders and outsiders thought expatriates should: Understand and respect the culture, norms and taboos of the people, and the business environment, in order to gain acceptance (35\% insiders; $44 \%$ outsiders). An outsider stated, "The traditional African style of leadership remains the most effective mainly because it is familiar. However, for democracy and concern for human rights to mature to the next level in most parts of Africa, there will need to be some modifications to the traditional African style of leadership."

All of the preliminary findings are presented in Tables 1 and
2. Table 1 presents commonalities in conjunction with differences between the two groups, and Table 2 lists the remaining commonalities. The information presented includes more commonalities than originally anticipated but this could be due to the small sample size.

Although "commonalities" refers to factors that were mentioned by both groups, it is also relevant to consider the differences in emphasis. For example, being firm, dictating work, and so on was more important to insiders (59\%) than it was to outsiders (13\%), and showing respect to subordinates was more important to outsiders $(50 \%)$ than it was to insiders (24\%). These differences in emphasis are worthy of further exploration.

\section{Conclusion and Implications}

Although we are at the beginning of this phase of the research and the findings are limited and need to be expanded, they support those of earlier emic and etic studies (Lituchy et al., 2017), and other studies on leadership (Avolio et al., 2009; Northouse, 2016; Osland, 2008; Van Vugt et al., 2008). For example, while many of the insiders and outsider said they use an authoritarian or mixed leadership style, they also suggested using many aspect of transformational leadership. This is also similar to the LEAD Mexico results (also in this issue), where both insiders and outsiders stated that managers who exhibit transformational behaviors are more effective leaders. While it was anticipated that transformational leadership would be prevalent, a greater difference was expected since most Western expatriates bring their individualistic home country view into an African setting, which is often more

Table 2: Commonalities between Insiders and Outsiders

\begin{tabular}{|c|c|c|}
\hline Show respect to subordinates & Insiders \% & Outsiders \% \\
\hline Be serious; fair; honest; respect time; and show integrity in terms of managerial and public leadership & 47 & 50 \\
\hline Listen to everyone who has been there long-term & 24 & 50 \\
\hline Consider the level of education upon dealing with people & 35 & 44 \\
\hline Give clear instructions and directions & 6 & 38 \\
\hline Constantly check progress & 10 & 6 \\
\hline Bnderstand and respect the culture, norms and taboos of the people, and the business environment, in order to gain acceptance & 12 & 19 \\
\hline The relationship between local leaders and their subordinates should not be influenced by their personal relationship & 18 & 19 \\
\hline A mixed leadership style is appropriate & 24 & 13 \\
\hline Focus on capacity-building, developing subordinated, and accountability & 59 & 18 \\
\hline & 77 & 44 \\
\hline & 18 & 6 \\
\hline
\end{tabular}


communal. In this limited study this key difference was not highlighted, however further research should be conducted with larger sample sizes to more extensively discuss how this factor can possibly cause miscommunication or misunderstanding between expatriate leaders and local workers.

Indeed, further research is needed in Africa, as well as the African Diaspora. This distinction is crucial as the views of Africans and those in the African Diaspora, with the largest populations in Brazil, the United States, and Haiti, for example have different cultural norms and perspectives that may create differing views on effective leadership. These groups have been extensively studied separately and concurrently in historical contexts, yet not in terms of leadership effectiveness.

This initial study provides some early insights on effective leadership that may be used to advance cross-cultural leadership theory as well as practice. Implications of these insights suggest incorporating effective leadership practices from other parts of the world into African organizations.

\section{References}

Aseidu-Appiah, F., Agyapong, A., \& Lituchy, T.R. 2017. Leadership in Ghana. In T. R. Lituchy, B. Galperin, \& B. J. Punnett (Eds), LEAD: Leadership Effectiveness in Africa and the African Diaspora. London: Palgrave MacMillan.

Avolio, B. J., Walumbwa, F. O., \& Weber, T. J. 2009. Leadership: Current theories, research, and future directions. Annual Review of Psychology, 60: 421-449.

Cox, T. H., Lobel, S. A., \& McLeod, P. L. 1991. Effects of ethnic group cultural differences on cooperative and competitive behavior on a group task. Academy of Management Journal, 34(4): 827-847.

Lituchy, T. R., Galperin, B. L., \& Punnett, B. J. 2017. LEAD: Leadership effectiveness in Africa and the African Diaspora. London: Palgrave Macmillan.

Lituchy, T. R., \& Punnett, B. J. 2014. Leadership Effectiveness and Motivation in Africa and the African Diaspora (LEAD): An Introduction. Canadian Journal of Administrative Sciences, 31: 221-227.

Mengitsu, A. B., \& Lituchy, T. R. 2017. Leadership in Ethiopia. In T. R. Lituchy, B. Galperin, \& B. J. Punnett (Eds), LEAD: Leadership effectiveness in Africa and the African Diaspora. London: Palgrave Macmillan.

Metwally, E. K., \& Punnett, B. J. 2017. Leadership in Egypt. In T. R. Lituchy, B. Galperin, \& B. J. Punnett (Eds), LEAD: Leadership effectiveness in Africa and the African Diaspora. London: Palgrave Macmillan.

Northouse, P. G. 2016. Leadership theory and practice. London: Sage.

Osland, J. S. 2008. Global leadership. AlB Insights, 8(1): 10-11.

Van Vugt, M., Hogan, R., \& Kaisar, R. B. 2008. Leadership, followership, and evolution: Some lessons from the past. American Psychologist, 63(3): 182.
Zhang, X., Fu, P., Xi,Y., Xu, L., Cao, C., Li, G., Ma, L. \& Ge, J. 2012. Understanding indigenous leadership research: Explication and Chinese examples. The Leadership Quarterly, 23: 1063-1079.

Terri R. Lituchy (terrilituchy@yahoo.com) holds a Ph.D., University of Arizona and is PIMSA Distinguished Chair and Professor, CETYS Universidad (Mexico). She has taught around the world and published extensively in international journals. Dr. Lituchy has received awards and grants, from SAMS, SHRM, SSHRC, Emerald Publishing, McMaster, Concordia, and University of the West Indies. Books include Successful Professional Women of the Americas, Gender and the Dysfunctional Workplace, Management in Africa, and LEAD.

Elham Metwally (ekm@aucegypt.edu) is an Adjunct Assistant Professor at the American University in Cairo. She co-chaired the AFAM 2016 Conference and serves on the Editorial Board of the Africa Journal of Management. She has several publications, and her research and teaching interests include strategic management, organizational behavior and leadership, and human resources management. She worked at HSBC bank, and was the Director of Scholarships at the American University in Cairo.

Courtney Aleise Henderson (Courtney-Henderso@BerkeleyCollege.edu) holds an M.A., University of Toledo; M.S., University of Hawaii, Higher Education Certification, Harvard and is working on an Ed.D. in Higher Education. She has worked at Berkeley College, the University of Miami, and Pharos University. As Director of the Semester at Sea Writing Center, she gave 7 presentations. Henderson earned grants to create a Hawaiian/Englishs book and game helping with Hawaiian language revitalization. Henderson has presented at several international conferences.

\section{AIB INSIGHTS}

